\title{
Study of Heat Treatment in Processing of Pumpkin Puree (Cucurbita moschata)
}

\author{
L. C. O. Santos Jr. ${ }^{1}$, Vanessa Simão ${ }^{2}$, Júlia dos Santos Opuski de Almeida ${ }^{3}$, Ana Carolina Moura de Sena Aquino ${ }^{3}$, \\ Eduardo Carasek ${ }^{2}$ \& Edna Regina Amante ${ }^{1,3}$ \\ ${ }^{1}$ Department of Food Chemistry and Food Engineering, Federal University of Santa Catarina, Campus \\ Universitário Trindade, Florianópolis, SC, Brazil \\ ${ }^{2}$ Department of Chemistry, Federal University of Santa Catarina, Campus Universitário Trindade, Florianópolis, \\ SC, Brazil \\ ${ }^{3}$ Fruits and Vegetables Technological Laboratory, Food Science and Technology Department, Federal University \\ of Santa Catarina, Campus Itacorubi, Florianópolis, SC, Brazil
}

Correspondence: Edna R. Amante, Fruits and Vegetables Technological Laboratory, Food Science and Technology Department, Federal University of Santa Catarina, Campus Itacorubi, Florianópolis, SC 88040-900, Brazil. Tel: 55-48-3721-6290. E-mail: e.amante@ufsc.br

\author{
Received: July 20, 2017 Accepted: August 31, $2017 \quad$ Online Published: September 15, 2017 \\ doi:10.5539/jas.v9n10p234 URL: https://doi.org/10.5539/jas.v9n10p234
}

The research is financed by CNPq-Brazil.

\begin{abstract}
Pumpkins have richness of nutrients and in puree form may contribute to their greater appreciation in the vegetable processing industry. However, studies are necessary for its processing, since it is part of the group of risk of microbial contamination ( $\mathrm{pH}>4.5$ ). Thus, this work aimed to study the pumpkin puree processing by heat treatment in autoclave wherein the product was subjected to sterilization by autoclaving at $121{ }^{\circ} \mathrm{C}$ to check their microbial load and physicochemical characteristics and to identify the volatile compounds of headspace in stand up pouch packaging. The heat treatment in autoclave for 10,20 and 30 minutes was effective in eliminating microbial load of the sample $\left(<1.0 \times 10^{1}\right)$ and also induced the decrease of $\mathrm{pH}$ and increase of titratable acidity (TA), total soluble solids (TSS) and total carotenoids. The compounds identified in the headspace after autoclaving were alcohols, aldehydes, alkenes, ketones, esters, ethers and terpenes, many of them aromatic compounds that characterize pumpkin and carotenoid degradation products and acids that justify physicochemical changes after processing.
\end{abstract}

Keywords: pumpkin puree, sterilization, volatile compounds, heat treatment

\section{Introduction}

Pumpkins occupy a prominent place among vegetables due to its high productivity worldwide, in addition to cooking versatility, richness of nutrients (carotenoids, vitamins, aminoacids etc.), phenolic compounds, antioxidant activity, properties against cancer and sterols that convert into vitamin D stimulating cell differentiation. They have a long shelf life, low calories, large amount of fiber in the pulp and seeds and few solids(Caili et al., 2007; Gliemmo, Latorre, Gerschenson, \& Campos, 2009; Jacobo-Valenzuela, Maróstica-Junior, Zazueta-Morales, \& Gallegos-Infante, 2011; Nawirska-Olszanska, Biesiada, Sokol-Letowska, \& Kucharska, 2014). The pumpkin pulp variety "menina brasileira" (Cucurbita moschata) is rich in pectin and carotene, such as $\alpha, \beta$ and lycopene, which have antioxidant properties, especially $\beta$-carotene as a precursor of vitamin A (Azevedo-Meleiro \& Rodriguez-Amaya, 2007; Gliemmo et al., 2009; Provesi, Dias, \& Amante, 2011; Nawirska-Olszanska et al., 2014).

Pumpkin puree is an intermediate product thermally processed to produce jams, jellies, drinks and other products with considerable added value and which are of interest from the nutritional point of view. The cooking step is mainly responsible for a decrease in the concentration of carotenes. Studies need to be conducted to investigate the compositional changes which occur during processing. In pumpkin puree, there is a risk of microbial contamination due to the nutrient content and physicochemical parameters (e.g. $\mathrm{pH}>4.5)$. Besides the 
application of good manufacturing practices throughout the processing procedure, the heat treatment applied must be efficient.

Pumpkin processing studies are scarce and predominantly deal with thermal processing, but not about the losses in nutrient composition. Provesi et al. (2011) studied the storage of processed pumpkin puree in glass containers and did not observe significant changes in $\mathrm{pH}$, acidity and total soluble solids, under favorable conditions $(\mathrm{T}<$ $30{ }^{\circ} \mathrm{C}$, protected from light), verifying the stability of the puree (Gliemmo et al., 2009). High levels of oxidative degradation of PUFAs (polyunsaturated fatty acids) and carotenoids were detected after high pressure sterilization at high temperature (Kebede et al., 2014).

The carotenoid content, responsible to the color, is another important quality index, because its chain of unsaturated carbons is susceptible to some reactions, such as oxidation and isomerization during processing and storage of food, thus changing nutritional value (Gliemmo et al., 2009; Provesi, Dias, Amboni, \& Amante, 2012).

Several factors can affect the stability of carotenoids, such as type and shape, oxygen concentration, metal presence, light exposure, heat treatment, matrix, among others (Rodriguez-Amaya, 1999; Provesi et al., 2011). Although carotenoids are moderately thermostable, the effects of the modifications by thermal treatment are: loss of color, biological activity and formation of volatile compounds that cause undesirable flavors (Rodriguez-Amaya, 1999; Ayvaz et al., 2012). Due to the instability, most of the pumpkin puree processing causes degradation of carotenoids. Depending on the severity of the heat treatment used, isomerization, oxidative degradation and other reactions can be induced (Gama \& Sylos, 2007; Ayvaz et al., 2012).

In pumpkin purees, the cooking step was the main responsible for the reductions in carotenoid concentration (Provesi et al., 2011). Foods with high content of pectin and fibers, such as the pumpkin, confer some stability in processing (Marx, Stuparic, Schieber, \& Carle, 2003). After heat treatment, it is also easier to extract carotenoids, producing an increase in their total content in relation to fresh vegetables, result that may be associated with the higher bioavailability of these compounds from the heat-treated plant matrix (Van Het Hof, West, Weastrate, \& Hautvast, 2000). Studies on the consequences of processing and storage on the carotenoid composition in pumpkin puree are important because they may be unstable at high temperatures (Kebede et al., 2014).

Fruit and derivatives usually have a complex composition of volatile constituents. However, it is known that only a fraction of the volatile compounds is directly involved in the quality of the aroma and flavor of the fruits presenting different odoriferous impacts (Wang et al., 2009; Damiani et al., 2009; Souza Galvão, Narain, Santos, $\&$ Nunes, 2011). There is a great diversity of fruits that have not yet been explored for volatile compounds, such as pumpkin.

The research involving volatile compounds starts with a step of isolating and concentrating volatile fraction through a specific extraction method, followed by a chromatographic analysis, in which separation, quantification and/or identification of the analytes will occur and the data will be processed (Valente \& Augusto, 2000). The determination of volatile compounds that volatilize from the matrix is important since they are responsible for aroma and flavor, and consequently, acceptance of the product, as well as indications of changes during the heat treatment or processing. This group includes compounds such as aldehydes, alcohols, ketones, terpenes, ethers, esters, furans and hydrocarbons. Usually they are in the headspace of a package (Pawliszyn, 1997).

Heat treatment is one of the most important methods of preserving food and has the main purpose of inactivating enzymes, pathogens and other deteriorating microorganisms capable of rendering them improper for consumption. It is also used to improve the bioavailability of nutrients, such as carotenoids, since it breaks down the structures of the plant cell and may change the sensory and nutritional properties of the product (Dutta, Dutta, Raychaudhuri, \& Chakraborty, 2006; Alonso et al., 2013; Lau et al., 2015; Terefe et al., 2016). For stable low acidity products $(\mathrm{pH}>4.6)$ such as pumpkin puree, the industrial standard for application is at least a thermal processing equivalent to $121.1{ }^{\circ} \mathrm{C}$ for 3 minutes to achieve the lowest heating point of one product. Thermal processing in flexible retort pouches has been used as a common technique of preservation in the food industry for stability of low acid foods. Commercial processing in the retort pouch package ensures a reduction or inactivation of spore-forming microorganisms sufficient to ensure commercial stability (Byun et al., 2010). Some effects of packaging interaction with food matrix may occur, but little data is available on this aspect.

The objective of this work is to verify the effect of pumpkin puree placed in retort pouch packaging after heat treatment in an industrial autoclave, as a function of treatment time, analyzing the main chemical groups that volatilize the matrix and physicochemical changes of the processed product, as well as the efficiency of sterilization in elimination of the microbial load from the puree. 


\section{Materials and Methods}

\subsection{Raw Material}

Pumpkins of "menina brasileira" variety (Cucurbita moschata) were obtained from a commercial establishment of Florianópolis, farmed in Angelina city, Santa Catarina State (Brazil).

\subsection{Production of Pumpkin Puree}

The pumpkins were cleaned with a neutral detergent and washed to remove surface dirt. The samples were cut into slices and then boiled for $20 \mathrm{~min}$. The pieces were cooled and peeled and the seeds were removed. The puree was prepared through manual smashing with a fork. The puree was portioned and 30-50 g were placed in retort stand up pouch packages and submitted to several treatments.

\subsection{Pumpkin Purees Conditions for Analysis after Process}

The analyses of pumpkin puree packed in flexible pouch bags were performed in samples without sterilization (NSP-cooked non-sterile puree) and sterilized (SP-sterile puree) in autoclave at $121{ }^{\circ} \mathrm{C}$ for 10 (SP-10), 20 (SP-20) and 30 minutes (SP-30). The raw material without previous treatment (raw pumpkins) were also evaluated (INS-in nature sample). All analyses were performed in triplicate.

\subsection{Characterization of Pumpkin Puree}

Physicochemical analyses were performedon samples of fresh pumpkins, as well on purees before and after being sterilized and after. The physicochemical analyses were $\mathrm{pH}$-value, total soluble solids (TSS), titratable acidity (TA) and total carotenoids. The pHvalue was determined with a $\mathrm{pH}$ meter (Quimis, Diadema, Brazil). The TSS were measured at room temperature using a tropenmodell I refractometer (Carl Zeiss, Jena, Germany) and expressed as ${ }^{\circ}$ Brix (g sucrose per $100 \mathrm{~g}$-on a fresh basis). To determinate TA, the purees were diluted in water $(1: 50 \mathrm{v} / \mathrm{v})$ and the mixture was titrated with $0.1 \mathrm{~mol} \mathrm{~L}^{-1} \mathrm{NaOH}$ in the presence of phenolphthalein.

To determine the total carotenoids, the method proposed by Rodriguez-Amaya (2001) was adopted, with modifications in terms of weight and volume of samples and reagents. The carotenoids were completely extracted with cold acetone from 5 to $10 \mathrm{~g}$ of sample and after that they were partitioned in petroleum ether, washed with distilled water and then collected in a volumetric flask. All the necessary precautions in the carotenoid analysis were taken as suggested by Rodriguez-Amaya (1999). The carotenoid solution was made up to volume with petroleum ether and its absorbance was determined at $450 \mathrm{~nm}$ (U-1800 Hitachi, Tokyo, Japan). The total carotenoid content $\left(\mu \mathrm{g} \mathrm{g}^{-1}\right)$ was calculated by using the absorption coefficient of $\beta$-carotene in petroleum ether.

Microbiological analyses of pumpkin puree after heat treatment were performed according to the American Public Health Association-APHA (APHA, 2001). The microorganism indicative of sterilization of pumpkin puree was Clostridium sulphite reductive, because it is a bacterium of the group of mesophilic anaerobes which causes deterioration of acidic and acidic foods $(\mathrm{pH}>4.6)$ from fermentation of sugars, starch and pectin (Jay, 2005).

\subsection{Analysis of Volatile Compounds in the Headspace by SPME}

Samples of pumpkin puree not sterilized and sterilized at 10,20 and 30 minutes were evaluated for volatile composition in the headspace of the package by gas chromatography coupled to mass spectrometry (GC-MS). The non-sterile pumpkins puree was the control sample. All analyses were performed in duplicate.

The extraction of the compounds was carried out using the SPME in the headspace of the package, using the DVB/CAR/PDMS fiber (divinylbenzene, carboxen in polydimethylsiloxane) as the extracting phase $(50 / 30 \mu \mathrm{m}$ of thickness $/ 2 \mathrm{~cm}$ length) for partitioning the volatile compounds present in the sample. For this analysis, $50 \mathrm{~g}$ of pumpkin puree were considered enough to generate volatile compounds in the headspace. The pre-extraction equilibrium time for the sample to reach $40{ }^{\circ} \mathrm{C}$ was 10 minutes. Upon reaching this condition, the fiber was exposed into the headspace of the package at equilibrium temperature for 30 minutes to adsorption. After this, the SPME support was immediately taken to the injector (splitless mode) of the gas chromatograph (GC-MS QP-2010 Plus, Shimadzu, Kyoto, Japan).

The chromatograph was equipped with a capillary column Restek Rtx ${ }^{\circledR}-5 \mathrm{MS}$ (Restek, Bellefonte, PA, USA), in which the volatile compounds were desorbed at $250{ }^{\circ} \mathrm{C}$ for 10 minutes. The separation of the volatile compounds from the puree was carried out based on specific chromatographic conditions, consisting of heating ramp starting at $40{ }^{\circ} \mathrm{C}$ and maintaining for 4 minutes. After, the heating rate was $5{ }^{\circ} \mathrm{C} / \mathrm{min}$ until reaching $195{ }^{\circ} \mathrm{C}$. The carrier gas used was ultrapureHelium (He) $(99.99 \%)$ with a linear velocity of $36.1 \mathrm{~cm} \mathrm{~s}^{-1}$. The temperature of the interface and the ion source was $260{ }^{\circ} \mathrm{C}$ and $230{ }^{\circ} \mathrm{C}$, respectively. The mass spectrometer was operated in the 
electron impact mode (EI) with the source of ions operating at $70 \mathrm{eV}$. Identification of the volatile compounds was performed using a NIST 05 library software coupled to GC-MS. Only peaks with absolute intensity greater than 50000 and probability greater than $85 \%$ were considered.

\subsection{Statistical Analysis}

The statistical analysis was performed in triplicate $(n=3)$ and the results expressed as means \pm standard deviations. The data obtained were submitted to Tukey's means comparison test $(p<0.05)$ and treated using Statistica 7.0 (Statsoft, 2004).

\section{Results and Discussion}

The pumpkin (Cucurbita moschata) is a raw material of low acidity which was proven in this work. Cooking and subsequent sterilization had an effect on all parameters evaluated. The Clostridium sulphite reducing count under all conditions was $<1.0 \times 10^{1} \mathrm{CFUg}^{-1}$. Thus, it was concluded that the sterilization method was efficient.The applied process is delineated to reach at least $12 \mathrm{log}$ spore reduction of the pathogen Clostridium botulinum (Awuah, Ramaswamy, \& Economides, 2007; Leadley, Tucker, \& Fryer, 2008; Arias-Mendez, Vilas, Alonso, \& Balsa-Canto, 2014). Table 1 shows the physical-chemical characteristics of raw material (INS), cooked non-sterile (NSP) and sterile (SP-10, SP-20 and SP-30) pumpkin puree at $121^{\circ} \mathrm{C}$.

Table 1. Physicochemical characteristics of raw material (INS), cooked non-sterile pumpkin puree (NSP) and pumpkin puree sterilized at $121^{\circ} \mathrm{C}$ for 10 minutes (SP-10), 20 minutes (SP-20) and 30 minutes (SP-30).

\begin{tabular}{lllll}
\hline Samples & $\mathrm{pH}$ & $\mathrm{TA}\left(\% \mathrm{NaOH} \mathrm{mol} \mathrm{L}{ }^{-1}\right)$ & $\mathrm{TSS}^{\circ}$ Brix $)$ & Total carotenoids $\left(\mu \mathrm{g} \mathrm{g}^{-1}\right)$ \\
\hline INS & $6.89 \pm 0.06^{\mathrm{a}}$ & $0.53 \pm 0.12^{\mathrm{d}}$ & $4.63 \pm 0.15^{\mathrm{c}}$ & $247.95 \pm 6.37^{\mathrm{b}}$ \\
$\mathrm{NSP}$ & $6.14 \pm 0.02^{\mathrm{b}}$ & $2.17 \pm 0.12^{\mathrm{c}}$ & $5.00 \pm 0.00^{\mathrm{b}}$ & $336.58 \pm 3.52^{\mathrm{a}}$ \\
$\mathrm{SP}-10$ & $5.82 \pm 0.03^{\mathrm{c}}$ & $2.70 \pm 0.20^{\mathrm{b}}$ & $6.03 \pm 0.06^{\mathrm{a}}$ & $345.38 \pm 8.59^{\mathrm{a}}$ \\
$\mathrm{SP}-20$ & $5.87 \pm 0.05^{\mathrm{c}}$ & $2.63 \pm 0.12^{\mathrm{b}}$ & $6.17 \pm 0.06^{\mathrm{a}}$ & $340.29 \pm 2.03^{\mathrm{a}}$ \\
SP-30 & $5.70 \pm 0.04^{\mathrm{d}}$ & $3.23 \pm 0.12^{\mathrm{a}}$ & $6.17 \pm 0.15^{\mathrm{a}}$ & $343.27 \pm 5.43^{\mathrm{a}}$ \\
\hline
\end{tabular}

Note. *Lowercase letters compare means in the same column. Different letters correspond to significant change $(\mathrm{p}<0.05)$ by Tukey's test.

The $\mathrm{pH}$ of the food is one of the main intrinsic factors that determine the growth or survival of the microorganisms present. Optimum values for microorganism growth are close to neutrality. Based on the acidity classification of foods, pumpkin puree in all conditions was characterized as low acid food ( $\mathrm{pH}>4.6)$ (Jay, 2005; Provesi et al., 2011). The pumpkin in nature (INS) had a mean $\mathrm{pH}$ of $6.89 \pm 0.06$, being in agreement with the one found by Silva et al. (2009), which worked with the same cultivar (Cucurbita moschata) minimally processed with $\mathrm{pH}$ close to 7.50. B. M. Vilas Boas, Nunes, E. V. Vilas Boas, and Xisto (2006) found in the same cultivar 6.5 of $\mathrm{pH}$.

The difference can be attributed to genetic variations of the fruits, as well as to different stages of maturation, seasonality, cultivation conditions, soil and other factors. In heat-treated samples, there was a significant difference in $\mathrm{pH}$ values $(\mathrm{p}<0.05)$. This fact can be explained by the release of organic acids by cutting, slicing or grinding and also during the heat treatment. In SP-30, it was found that the heat treatment contributed to the reduction of pH (Rodriguez-Amaya, Kimura, \& Amaya-Farfan, 2008).

During sterilization, dehydration and hydrolysis occur, leading to a final product with predominance of acids, such as acetic and formic acid, which may also explain the increase of acidity and decrease of $\mathrm{pH}$ (Buckholz, 1988). In the work carried out by Provesi et al. (2011), the $\mathrm{pH}$ in pumpkin puree was $5.4 \pm 0.1$, close to that obtained in this research.

Acidity can indicate the state of conservation of a food product, aiding in the detection of chemical or microbiological decomposition processes. These changes in pumpkin puree were accompanied by titratable acidity (TA) and $\mathrm{pH}$ which are not always directly related either to the acid property, some buffering effect of the fruit or other factors (M. I. F. Chitarra \& A. B. Chitarra, 2005). TA in INS was low compared to heat treated pumpkin puree. Among the sterilized ones, it is observed that SP-30 had slight increase in acidity, probably due to formation of acidic compounds in this process. The presence of these acids is a factor that can affect the stability of carotenoids, such as hydrolyzed derivatives of pectin which correspond to galacturonic acid that may have contributed to these results. Thus, other compounds may undergo thermal hydrolysis (Rodriguez-Amaya, 1999; Rodriguez-Amaya et al., 2008). 
The TSS presented a mean value of $4.63 \pm 0.15$ in INS, which is inferior to the samples treated thermally. After steam cooking and sterilization, there was a slight increase in TSS, but there was no significant difference ( $\mathrm{p} \geq$ 0.05 ) between the sterilized samples (SP-10, SP-20 and SP-30), indicating that the autoclaving process did not change significantly this parameter and according to the studies done by Provesi et al. (2011), who obtained a mean of $6.5 \pm 0.1^{\circ} \mathrm{Brix}$ in pumpkin purees.

The results presented in Table 1 indicate that the total carotenoid content increased with sterilization and did not differ significantly $(\mathrm{p}<0.05)$ in all sterilization times. Rodriguez-Amaya (1999) explained that carotenoids are generally well preserved with most cooking methods. The application of heat may increase the availability of carotenoids, even though there are significant losses after and during the processing.Elevated temperatures with shorter time improved carotenoid retention in tomato juice sterilized at $121{ }^{\circ} \mathrm{C}$ for $40 \mathrm{~s}$ (Lin \& Chen, 2005). Heating in cashew juice induced appearance of cis isomers and epoxides, as well as the disappearance of some xantophylls during treatment, aggravated by the acids present in the juice (Zepka \& Mercadante, 2009).

The higher bioavailability of carotenoids in foods is achieved when humid heat is employed, while dry heat does not promote this effect (Sultana, Anwar, \& Iwbal, 2007). Provesi et al. (2011) reports that the relative stability of carotenoids in pumpkin purees was predicted because the factors that affect them were minimized by thermal processing, causing inactivation of enzymes that act in the degradation of these compounds.

Several studies present pumpkins with significant amounts of carotenoids. Azevedo-Meleiro and Rodriguez-Amaya (2007) found that Cucurbita moschata showed an increase of $5.4 \mu \mathrm{g} \mathrm{g}^{-1}$ to $79 \mu \mathrm{g} \mathrm{g}^{-1}$ during the maturation phase of the fruit. Ramos, Queiroz, Casali, and Cruz (1999) verified in several crosses of local varieties (hybrids) between $100.5 \mu \mathrm{g} \mathrm{g}^{-1}$ and $356.4 \mu \mathrm{g} \mathrm{g}^{-1}$. Amariz et al. (2009), when studying several pumpkins varieties of Brazilian Northeast, verified variations between 191.0 and $539.0 \mu \mathrm{g} \mathrm{g}^{-1}$, in agreement with those found in this work.

Some studies report alterations in purees with heat treatment which can be explained by the fact that higher temperatures favor reaction speeds, such as Maillard reaction, since the pumpkin has a high concentration of soluble sugars and proteins. In view of this fact, purees sterilized for 30 minutes (SP-30) showed sensory alterations in odor, matrix water loss and color, although they were sensorially and colorimetrically evaluated at this stage (Buckholz, 1988). During sterilization, dehydration and hydrolysis occur, reaching a final product with predominance of acids, such as acetic and formic, formation of aldehydes, such as formaldehyde and HMF, diacetyl, carbonyls and enol groups, which are responsible for aroma (have volatility) and color (Buckholz, 1988).

Analyzes of volatile compounds of pumpkin puree contained in flexible pouch packs were initiated after the choice of SPME fiber (Tables 2-5). The commercial fiber PDMS/CAR/DVB was chosen because it had a better performance in the identification of the compounds of headspace.

For non-sterile puree samples (NSP), only $10 \mathrm{~g}$ were used, because when using a larger amount of sample (more than $30 \mathrm{~g}$ ), there was a saturation of the mass detector (MS), which probably occurs due to the large concentration of volatile compounds. This fact is due to the SPME technique that makes a pre-concentration of the analytes and, as the detector has great sensitivity, it can be saturated even when small masses are used.

For the analysis of volatile compounds in SP-10, SP-20 and SP-30, $50 \mathrm{~g}$ of sample were used. Considering that no other work on the determination of volatiles in pumpkin puree placed in pouch packaging has been up to date, the results could be influenced by the lack of optimization and standardization of this methodology for this purpose. The extraction time of 30 minutes at $40{ }^{\circ} \mathrm{C}$ and injection in the $\mathrm{CG}$ for 10 minutes were sufficient to extract and identify volatile compounds from the samples.Tables $2-5$ shows the main volatile compounds identified by SPME analysis for all samples of pumpkin puree.

According to the results obtained by SPME (Tables 2-5), it was verified the formation of several compounds that characterize the puree as to its aromatic profile, such as $\beta$-ionone, $\alpha$ and $\beta$-cyclocyclal (known as carotenoid degradation products), safranal, terpenes, citronella, 2-carene, among others. The presence of acid esters, conjugated with oxalic acid and sulfuric acid, also justifies the changes in the physicochemical parameters, as well as the reduction in $\mathrm{pH}$ and increase in TA. 
Table 2. Main volatile compounds identified by headspace/SPME analysis for samples of cooked non-sterile pumpkin puree (NSP).

\begin{tabular}{|c|c|c|}
\hline Organic function & Main volatile compounds & $(\%)$ \\
\hline \multirow[t]{3}{*}{ Alcohol } & 4-methyl-1-hexanol & $1.25 \pm 0.63$ \\
\hline & 2-ethyl-1-pentanol & \\
\hline & 2-ethyl-1-butanol & \\
\hline \multirow[t]{2}{*}{ Aldehyde } & $\alpha$-methylbutanal & $0.05 \pm 0.01$ \\
\hline & Pentanal & \\
\hline \multirow[t]{6}{*}{ Alkene } & Toluene & $27.59 \pm 1.79$ \\
\hline & 1,3,5-cycloheptatriene & \\
\hline & 2,4-dimethyl-1-heptane & \\
\hline & 1,3-cyclopentadiene & \\
\hline & 1-octene & \\
\hline & o-xylene & \\
\hline \multirow[t]{3}{*}{ Ketone } & 2-pentanone & $1.25 \pm 0.55$ \\
\hline & 4-methyl-2-heptanone & \\
\hline & 4-(1,1-dimethyl-ethyl)-cyclohexanone & \\
\hline Ester & Oxalic acid & $0.18 \pm 0.51$ \\
\hline \multirow[t]{2}{*}{ Terpene } & $\alpha$-pinene & $0.63 \pm 0.74$ \\
\hline & 2-carene & \\
\hline
\end{tabular}

Table 3. Main volatile compounds identified by headspace/SPME analysis for samples of sterilized pumpkin puree (SP-10)

\begin{tabular}{|c|c|c|}
\hline Organic function & Main volatile compounds & $(\%)$ \\
\hline Alcohol & $\begin{array}{l}\text { 4,8-dimethyl-1-nonanol } \\
\text { Citronella } \\
\text { 2-propyl-heptanol } \\
\text { 1-octanol } \\
\text { Isotridecanol } \\
\text { 1-decanol } \\
\text { 2-isopropyl-5-methyl-1-heptanol }\end{array}$ & $7.12 \pm 1.44$ \\
\hline Aldehyde & $\begin{array}{l}\alpha \text {-methylpropionaldeyde } \\
\beta \text {-methylbutanal }\end{array}$ & $6.39 \pm 0.67$ \\
\hline Alkene & $\begin{array}{l}\text { Toluene } \\
1,3 \text {-cyclopentadiene }\end{array}$ & $2.03 \pm 0.33$ \\
\hline Ketone & $\begin{array}{l}\text { 4,4-dimethyl-2-pentanone } \\
\text { 1-(2,2-dimethylcyclopentil)-ethanone } \\
\alpha \text {-Ionone }\end{array}$ & $2.24 \pm 0.26$ \\
\hline Ester & $\begin{array}{l}\text { Oxalic acid } \\
\text { Sulfurous acid }\end{array}$ & $1.63 \pm 0.16$ \\
\hline
\end{tabular}


Table 4. Main volatile compounds identified by headspace/SPME analysis for samples of sterilized pumpkin puree (SP-20)

\begin{tabular}{|c|c|c|}
\hline Organic function & Main volatile compounds & $(\%)$ \\
\hline \multirow[t]{3}{*}{ Alcohol } & Isotridecanol & $4.00 \pm 0.81$ \\
\hline & 3,7-dimethyl-1-octane & \\
\hline & 2-isopropyl-5-methyl-1-heptanol & \\
\hline \multirow[t]{2}{*}{ Aldehyde } & $\alpha$-methylbutanal & $6.74 \pm 0.94$ \\
\hline & $\beta$-methylbutanal & \\
\hline \multirow[t]{4}{*}{ Alkene } & Toluene & $24.43 \pm 1.15$ \\
\hline & 2,4-dimethyl-1-heptene & \\
\hline & 1,3-cyclopentadiene & \\
\hline & Cyclohexene & \\
\hline \multirow[t]{3}{*}{ Ketone } & 2,2,6-trimethyl-cyclohexanone & $0.88 \pm 0.07$ \\
\hline & 3-methyl-4-heptanone & \\
\hline & 3,5-dimethyl-4-octanone & \\
\hline \multirow[t]{2}{*}{ Ester } & Oxalic acid & $1.65 \pm 0.11$ \\
\hline & Sulfurous acid & \\
\hline
\end{tabular}

Table 5. Main volatile compounds identified by headspace/SPME analysis for samples of sterilized pumpkin puree (SP-30)

\begin{tabular}{|c|c|c|}
\hline Organic function & Main volatile compounds & $(\%)$ \\
\hline \multirow[t]{7}{*}{ Alcohol } & 2-ethyl-1-butanol & $6.04 \pm 0.97$ \\
\hline & 2-isopropyl-5-methyl-1-hexanol & \\
\hline & 2-ethyl-1-hexanol & \\
\hline & Dihydro-citronelol & \\
\hline & 2-isopropyl-5-methyl-1-heptanol & \\
\hline & 2-ethyl-1-decanol & \\
\hline & 2-hexyl-1-decanol & \\
\hline \multirow[t]{4}{*}{ Aldehyde } & $\alpha$-methylbutanal & $14.26 \pm 1.34$ \\
\hline & 2-methyl-2-butenol & \\
\hline & n-heptanal & \\
\hline & $\beta$-cyclocitral & \\
\hline \multirow[t]{3}{*}{ Alkene } & Toluene & $9.05 \pm 0.92$ \\
\hline & 5-methyl-1-heptene & \\
\hline & Safranal & \\
\hline \multirow[t]{3}{*}{ Ketone } & $\alpha$-Ionone & $1.56 \pm 0.39$ \\
\hline & 2,2,6-trimethyl-ciclohexanone & \\
\hline & 4-methyl-2-heptanone & \\
\hline \multirow[t]{2}{*}{ Ester } & Oxalic acid & $0.32 \pm 0.07$ \\
\hline & Sulfurous acid & \\
\hline Eter & Hexyl-octyl-eter & $0.19 \pm 0.08$ \\
\hline Terpene & $\alpha$-pinene & $0.08 \pm 0.01$ \\
\hline
\end{tabular}

The sum of areas of peaks obtained from each functional group expressed absolute intensity of the compounds. The graphs (Figure 1) show a qualitative profile of the samples and that the compounds were not quantified. It can be seen that SP-30 had an absolute peak intensity higher than the other two conditions (SP-10 and SP-20). This may be related to the fact that the exposure of the sample to the heat for a longer time has caused a higher release of matrix compounds and also a higher degradation and formation of new compounds with aldehyde prevalence. 


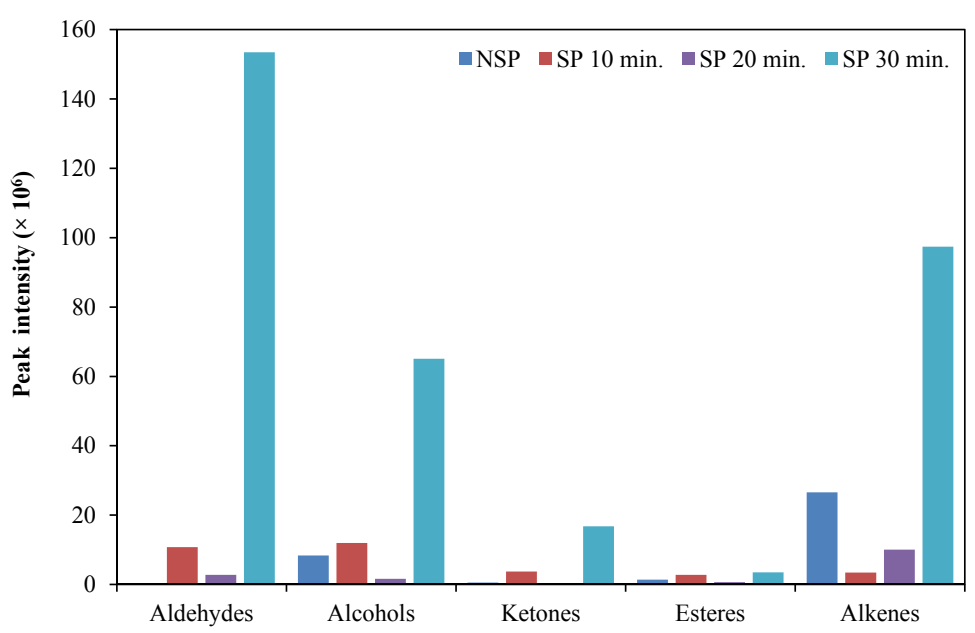

Figure 1. Comparison of the absolute intensity of chromatographic peaks, separated by functional group, in headspace/SPME analysis for the different pumpkin samples (NSP, SP-10, SP-20 and SP-30)

It is observed in Figure 1 that for all samples, except SP-30, the absolute intensity of the peaks remained close. As previously mentioned, the submission of the sample to sterilization for 30 minutes may be related to increase the degradation of compounds, formation of new compounds, such as aldehydes, and greater release of volatiles from the matrix. It can also be verified that the puree, before being submitted to sterilization, (NSP) showed a high concentration of alkenes.

Therefore, the effects of the heat treatment on the conditions used on pumpkin puree indicate consequences on the physicochemical characteristics and volatile composition expected for this product, without significantly compromising the inherent properties of this raw material.

\section{Conclusions}

Sterilization by autoclave results in total elimination of microbial load and significant changes in the physicochemical characteristics of pumpkin puree, mainly in acidification of the medium, but not to the point of considering the product as an acidic food $(\mathrm{pH}<4.6)$. Mainly identified in the headspace of pumpkin puree sterilized in pouch stand up packs, alkene functional groups, aldehydes, alcohols, ketones and esters. Many compounds of these groups are involved in the characterization of the aromatic profile of pumpkin puree, as well as components of carotenoid degradation and acidification of the medium.

\section{Acknowledgements}

Authors are grateful to the CNPq (Conselho Nacional de Desenvolvimento Científico e Tecnológico, Brazil) for their financial support and to CAPES (Coordenação de Aperfeiçoamento de Pessoal de Nível Superior) for the scholarships.

\section{References}

Alonso, A. A., Arias-Méndez, A., Balsa-Canto, E., Garcia, M. R., Molina, J. I., Vilas, C., \& Villafín, M. (2013). Real time optimization for quality control of batch thermal sterilization of prepackaged foods. FoodControl, 32(2), 392-403. https://doi.org/10.1016/j.foodcont.2013.01.002

Amariz, A., Lima, M. A. C., Borges, R. M. E., Belém, S. F., Passos, M. C. L. M. S., Trindade, D. C. G., \& Ribeiro, T. P. (2009). Caracterização da qualidade comercial e teor de carotenoides em acessos de abóbora. Horticultura Brasileira, 27(2), s541-s547.

APHA (American Public Health Association). (2001). Committee on Microbiological Methods for Foods. Compendium of methods for the microbiological examination of foods (4th ed.). Washington, DC.

Arias-Mendez, A., Vilas, C., Alonso, A. A., \& Balsa-Canto, E. (2014). Time-temperature integrators as predictive temperature sensors. Food Control, 44, 258-266. https://doi.org/10.1016/j.foodcont.2014.04.001

Awuah, G. B., Ramaswamy, H. S., \& Economides, A. (2007). Thermal processing and quality: Principles and overview. Chemical Engineering and Processing, 46(6), 584-602. https://doi.org/10.1016/j.cep.2006.08.004 
Ayvaz, H., Schirmer, S., Parulekar, Y., Balasubramaniam, V. M., Somerville, J. A., \& Daryaei, H. (2012). Influence of selected packaging materials on some quality aspects of pressure-assisted thermally processed carrots during storage. LWT-Food Science and Technology, 46(2), 437-447. https://doi.org/10.1016/ j.lwt.2011.12.004

Azevedo-Meleiro, C. H., \& Rodriguez-Amaya, D. B. (2007). Qualitative and quantitative differences in carotenoid composition among Cucurbita moschata, Cucurbita maxima and Cucurbita pepo. Journal of Agricultural and Food Chemistry, 55(10), 4027-4033. https://doi.org/10.1021/jf063413d

Buckholz, L. L. (1988). The role of Maillard technology in flavoring food products. Cereal Foods World, 33(7), 547-551.

Byun, Y., Bae, H. J., Cooksey, K., \& Whiteside, S. (2010). Comparison of the quality and storage stability of salmon packaged in various retort pouches. LWT-Food Science and Technology, 43(3), 551-555. https://doi.org/10.1016/j.lwt.2009.10.001

Caili, F., Haijun, T., Tongyi, C., Yi, L., \& Quanhong, L. (2007). Some properties of an acidic protein-bound polysaccharide from the fruit of pumpkin. Food Chemistry, 100(3), 944-947. https://doi.org/10.1016/ j.foodchem.2005.10.049

Chitarra, M. I. F., \& Chitarra, A. B. (2005). Pós-colheita de frutas e hortaliças. Lavras, BR: UFLA.

Damiani, C., Boas, E. V. B. V., Ferri, P. H., Pinto, D. M., \& Rodrigues, L. J. (2009). Volatile compounds profile of fresh-cut peki fruit stored under different temperatures. Food Science and Technology (Campinas), 29(2), 435-439. https://doi.org/10.1590/S0101-20612009000200032

Dutta, D., Dutta, A., Raychaudhuri, U., \& Chakraborty, R. (2006). Rheological characteristics and thermal degradation kinetics of beta-carotene in pumpkin puree. Journal of Food Engineering, 76(4), 538-546. https://doi.org/10.1016/j.jfoodeng.2005.05.056

Gama, J. J. T., \& Sylos, C. M. (2007). Effect of thermal pasteurization and concentration on carotenoid composition of Brazilian valencia orange juice. Food Chemistry, 100(4), 1686-1690. https://doi.org/ 10.1016/j.foodchem.2005.01.062

Gliemmo, M. F., Latorre, M. E., Gerschenson, L. N., \& Campos, C. A. (2009). Color stability of pumpkin (Cucurbita moschata, Duchesne ex Poiret) puree during storage at room temperature: Effect of $\mathrm{pH}$, potassium sorbate, ascorbic acid and packaging material. LWT-Food Science and Technology, 42(1), 196-201. https://doi.org/10.1016/j.1wt.2008.05.011

Jacobo-Valenzuela, N., Maróstica-Junior, M. R., Zazueta-Morales, J. J., \& Gallegos-Infante, J. A. (2011). Physicochemical, technological properties, and health-benefits of Cucurbita moschata Duchense vs. Cehualca: A review. Food Research International, 44, 2587-2593. https://doi.org/10.1016/j.foodres.2011. 04.039

Jay, J. M. (2005). Microbiologia de Alimentos. Porto Alegre: Artmed.

Kebede, B. T., Grauwet, T., Mutsokoti, L., Palmers, S., Vervoort, L., Hendrickx, M., \& Van Loey, A. (2014). Comparing the impact of high pressure high temperature and thermal sterilization on the volatile fingerprint of onion, potato, pumpkin and red beet. Food Research International, 56, 218-225. https://doi.org/10.1016/ j.foodres.2013.12.034

Lau, W. L., Reizes, J., Timchenko, V., Kara, S., \& Kornfeld, B. (2015). Heat and mass transfer model to predict the operational performance of a steam sterilizationautoclave including products. International Journal of Heat and Mass Transfer, 90, 800-811. https://doi.org/10.1016/j.ijheatmasstransfer.2015.06.089

Leadley, C., Tucker, G., \& Fryer, P. (2008). A comparative study of high pressure sterilization and conventional thermal sterilization: quality effects in green beans. Innovative Food Science \& Emerging Technologies, 9(1), 70-79. https://doi.org/10.1016/j.ifset.2007.06.005

Lin, C. H., \& Chen, B. H. (2005). Stability of carotenoids in tomato juice during processing. European Food Research and Technology, 22l(3-4), 274-280. https://doi.org/10.1007/s00217-005-1155-y

Marx, M., Stuparic, M., Schieber, A., \& Carle, R. (2003). Effects of thermal processing on trans-cis-isomerization of $\beta$-carotene in carrot juices and carotene containing preparations. Food Chemistry, 83(4), 609-617. https://doi.org/10.1016/S0308-8146(03)00255-3 
Nawirska-Olszanska, A., Biesiada, A., Sokol-Letowska, A., \& Kucharska, A. Z. (2014). Characteristics of organic acids in the fruit of different pumpkin species. Food Chemistry, 148, 415-419. https://doi.org/ 10.1016/j.foodchem.2013.10.080

Pawliszyn, J. (1997). Solid phase microextraction: Theory and practice. Toronto, Canada: Wiley-VCH.

Provesi, J. G., Dias, C. O., \& Amante, E. R. (2011). Changes in carotenoids during processing and storage of pumpkin puree. Food Chemistry, 128(1), 195-202. https://doi.org/10.1016/j.foodchem.2011.03.027

Provesi, J. G., Dias, C. O., Amboni, R. D. M. C., \& Amante, E. R. (2012). Characterisation and stability of quality indices on storage of pumpkin (Cucurbita moschata and Cucurbita maxima) purees. International Journal of Food Science \& Technology, 47(1), 67-74. https://doi.org/10.1111/j.1365-2621.2011.02808.x

Rodriguez-Amaya, D. B. (1999). Latin American Food Sources of Carotenoids. Archivos Latinoamericanos de Nutrición, 49(3), 74s-84s.

Rodriguez-Amaya, D. B. (2001). A guide to carotenoid analysis in foods. Washington: International Life Sciences Institute (ILSI).

Rodriguez-Amaya, D. B., Kimura, M., \& Amaya-Farfan, J. (2008). Fontes de carotenoides: tabela brasileira de composição de carotenoides em alimentos. Brasília: Ministério de Meio Ambiente/Secretaria de Biodiversidade e Florestas.

Silva, A. V. C., Oliveira, D. S. N., Yaguiu, P., Camelossi, M. A. G., Muniz, E. M., \& Narain, N. (2009). Temperature and packaging of minimally processed pumpkin (Cucurbita moschata). Ciência e Tecnologia de Alimentos, 29(2), 391-394. https://doi.org/10.1590/S0101-20612009000200025

Souza Galvão, M., Narain, N., Santos, M. S. P., \& Nunes, M. L. (2011). Volatile compounds and descriptive odor attributes in umbu (spondias tuberosa) fruits during maturation. Food Research International, 44(7), 1919-1926. https://doi.org/10.1016/j.foodres.2011.01.020

Sultana, B., Anwar, F., \& Iwbal, S. (2006). Effect of different cooking methods on the antioxidant activity of some vegetables from Pakistan. International Journal of Food Science and Technology, 43(3), 560-567. https://doi.org/10.1111/j.1365-2621.2006.01504.x

Terefe, N. S., Tepper, P., Ullman, A., Knoerzer, K., \& Juliano, P. (2016). High pressure thermal processing of pears: effect on endogenous enzyme activity and related quality attributes. Innovative Food Science and Emerging Technologies, 33, 56-66. https://doi.org/10.1016/j.ifset.2015.12.001

Valente, A. L. P., \& Augusto, F. (2000). Microextração por fase sólida. Química Nova, 23(4), 523-530. https://doi.org/10.1590/S0100-40422000000400016

Van Het Hof, K. H., West, C. E., Weastrate, J. A., \& Hautvast, J. G. A. J. (2000). Dietary factors that affect the bioavailability of carotenoids. Journal of Nutrition, 130(3), 503-506.

Vilas Boas, B. M., Nunes, E. E., Vilas Boas, E. V. B., \& Xisto, A. L. R. P. (2006). Influência do tipo de corte na qualidade de abobrinha 'menina brasileira' minimamente processada. Congresso Brasileiro de Olericultura, 46. Goiânia: Abh. https://doi.org/10.1590/S0102-05362006000200024

Wang, Y., Yang, C., Li, S., Yang, L., Wang, Y., Zhao, J., \& Jiang, Q. (2009). Volatile characteristics of 50 peaches and nectarines evaluated by HP-SPME with GC-MS. Food Chemistry, 116(1), 356-364. https://doi.org/ 10.1016/j.foodchem.2009.02.004

Zepka, L. Q., \& Mercadante, A. Z. (2009). Degradation compounds of carotenoids formed during heating of a simulated cashew apple juice. Food Chemistry, 117(1), 28-34. https://doi.org/10.1016/j.foodchem.2009. 03.071

\section{Copyrights}

Copyright for this article is retained by the author(s), with first publication rights granted to the journal.

This is an open-access article distributed under the terms and conditions of the Creative Commons Attribution license (http://creativecommons.org/licenses/by/4.0/). 